\title{
Teaching Food System Sustainability in Dietetic Programs: Need, Conceptualization, and Practical Approaches
}

\section{Authors: Alison H. Harmon, Julia Lapp, Dorothy Blair, and Annie Hauck-Lawson}

This is an Accepted Manuscript of an article published in Journal of Hunger \& Environmental Nutrition January 2011, available online:

http://www.tandfonline.com/10.1080/19320248.2011.554272

Harmon, Alison H., Julia Lapp, Dorothy Blair, and Annie Hauck-Lawson. "Teaching Food System Sustainability in Dietetic Programs: Need, Conceptualization, and Practical Approaches." Journal of Hunger \& Environmental Nutrition 6, no. 1 (January 2011): 114-124.

doi:10.1080/19320248.2011.554272.

Made available through Montana State University's $\underline{\text { ScholarWorks }}$

scholarworks. montana.edu 


\title{
Teaching Food System Sustainability in Dietetic Programs: Need, Conceptualization, and Practical Approaches
}

\author{
ALISON HARMON, ${ }^{1}$ JULIA L. LAPP,${ }^{2}$ DOROTHY BLAIR, ${ }^{3}$ \\ and ANNIE HAUCK-LAWSON ${ }^{4}$ \\ ${ }^{1}$ Foods and Nutrition, Montana State University, Bozeman, MT \\ ${ }^{2}$ Department of Health Promotion and Physical Education, \\ Ithaca College, Ithaca, New York \\ ${ }^{3}$ Department of Nutritional Sciences and Science, Technology and Society Program, \\ Penn State University, University Park, PA \\ ${ }^{4}$ Department of Health and Nutrition Sciences, Brooklyn College, Brooklyn, NY
}

Contemporary globalized food systems add new dimensions to the conceptualization of "bealthy" food. The need to address biophysical, social, and environmental aspects of food systems is internationally recognized. In a survey of 265 dietetics programs, 68\% of 145 educators were interested in sustainability education techniques yet felt inadequately prepared. We report on survey results and provide strategies for sustainability education (1) conceptually, as sustainable food system action goals; and (2) pedagogically, as didactic approaches to teaching that promote the sustainability goals, examples of teaching methods, and a selected reference list on sustainable food issues linked with the goals.

KEYWORDS nutrition education, sustainability, food systems, nutrition pedagogy

\section{INTRODUCTION: THE FOOD AND NUTRITION SYSTEM}

During the past century, an increasingly industrialized and globalized system of food production has resulted in goods and practices that are often problematic to human and ecological health. ${ }^{1-4}$ These problems include global

Address correspondence to Julia L. Lapp, PhD, RD, CDN, Assistant Professor, Department of Health Promotion and Physical Education, Hill Center 29, Ithaca College, Ithaca, NY 14850. E-mail: jlapp@ithaca.edu 
under- and overnutrition, ${ }^{5,6}$ accelerated resource depletion and pollution, ${ }^{7-13}$ contamination with pathogenic microbes, ${ }^{14}$ antibiotic resistance, ${ }^{15}$ and destabilization of the economies of food production in rural communities around the world. ${ }^{16,17}$ For example, in the United States, overweight and obesity have increased dramatically since 1985, at which time only 8 states had obesity prevalence of greater than 10\%; by 2008 all states exceeded $10 \%$ prevalence, and in 6 states more than 30\% of adults were obese. ${ }^{18}$ In 2007 , daily caloric consumption was $500 \mathrm{kcal} /$ day above 1972 to 1983 levels, the period just predating the obesity epidemic. ${ }^{19}$ Overweight and obesity are related to transitions away from traditional diets, inactivity, and the globalization of nutrient-poor commercial food, heavily dependent on fat and sugar. ${ }^{20}$

Coinciding with obesity and rising levels of diabetes are increasing rates of hunger, food insecurity, ${ }^{6,21}$ climate fluctuations leading to drought and floods in subsistence areas, ${ }^{11}$ and unprecedented degradation of the land, water, and mineral resources needed to produce food. ${ }^{3,14,15}$ The United Nations Food and Agriculture Organization (UN FAO) estimated that 18\% of global climate change (also land degradation, nitrogen pollution, and water overuse) is due solely to livestock, ${ }^{14}$ and more recent evidence more than doubles that estimate. ${ }^{13}$ In response to these trends, nutritionists and other health professionals have called for a "new paradigm" of nutritional science and food systems that integrate the biophysical aspects of nutritional health with social and environmental antecedents and outcomes. For example, in 2005 the International Union of Nutrition Scientists (IUNS) created the Giessen Declaration, which stated, "The purpose of nutrition science is to contribute to a world in which present and future generations fulfill their human potential, live in the best of health, and develop, sustain and enjoy an increasingly diverse human, living, and physical environment." $22(\mathrm{p} 4)$ Other professional organizations taking similar positions include the American Public Health Association (APHA), ${ }^{23}$ the American Medical Association (AMA), ${ }^{24}$ and the American Dietetic Association (ADA) ${ }^{25}$ As a result, there is an increasing call on dietetic professionals to participate in policy and public education that supports the redirecting of contemporary food systems toward sustainability. ${ }^{26,27}$ To effectively accomplish this, dietetic professionals need to be knowledgeable about and engaged with multiple aspects of the food system as it relates to sustainability. We maintain that education in this area can best occur within ADA-accredited dietetic training programs, yet the limited evidence suggests that many faculty feel unprepared to teach these topics to their students.

\section{TEACHING FOOD SYSTEMS AND SUSTAINABILITY IN THE DIETETIC CURRICULUM: RESULTS OF A SURVEY}

To facilitate enhanced understanding of food system issues among nutrition educators in dietetic training programs, it is crucial to pinpoint their 
current attitudes, needs, and interpretations of sustainability. Little evidence has been gathered to date to assess the knowledge, skills, and comfort levels of nutrition and dietetics faculty with teaching about food systems and sustainability. In 2006, a survey of faculty teaching in ADA-accredited didactic and coordinated programs was conducted. ${ }^{28,29}$ Results of this survey provide a baseline, as well as evidence of growing interest among dietetic educators in integrating sustainability and food systems education into traditional programs.

\section{Survey Instrument}

The 4-part Likert-scaled survey assessed the following: the extent to which concepts related to the food system and sustainability are taught in current dietetic coursework, the relative importance that educators place on various food system topics, attitudes among dietetic educators on these topics, and the resource needs of educators to expand teaching in this area.

\section{RESULTS}

One hundred and forty-five faculty responded. Most (84\%) had been practicing dietetics for 10 years or more, and the majority (62\%) had been teaching for 10 years or more. The sample included educators from all US regions, and participants were currently teaching coursework typically part of a dietetic curriculum. Of all of the dietetics courses reported by respondents, Community Nutrition was the one for which most faculty (41\% of all faculty teaching Community Nutrition) reported that they included content about food systems and sustainability.

\section{Sustainable Food Systems Topics}

Survey participants were given a list of potential food system and sustainability topics and asked to rate the importance of each (5, very important; 1 , very unimportant). Topics regarded as most important included community food security (average score was 4.34), genetic engineering (4.3), contamination of fish/food safety (4.25), water quality (4.25), and seasonally available foods (4.2). The topics seen as less important fell into 3 general categories: agricultural production issues (eg, use of antibiotics in animal agriculture, 3.84), rural community issues (eg, preservation of rural communities, 3.64), and social justice issues (eg, living conditions of farm laborers, 3.28). Though terms such as food, food choices, food safety, and water appear to influence scoring on importance, topics seen as more closely related to agriculture, natural resources, or social issues are regarded as less important or perhaps outside of the purview of nutritional science and 
dietetics. For example, agricultural economic viability (3.8) ranked lower on the list, but the relationship between food choices and the local economy neared the top (4.18). Water quality ranked higher on the list than ecological sustainability (4.0). Locally grown foods (4.04) ranked higher than farmland protection (3.58). Contamination of fish/food safety ranked higher than depletion of wild fish stocks (3.26). Other topics included plant-based diets (4.14), food and agricultural policies (4.10), irradiation (4.04), food marketing and advertising (4.04), social justice in the food system (3.88), use of synthetic chemicals/pesticides (3.83), soil quality (3.83), organic agriculture (3.82), use of hormones in animal agriculture (3.77), biodiversity (3.67), energy use in the food system (3.62), use of synthetic fertilizers (3.57), fair trade (3.46), food miles (3.40), integrated pest management (3.39), wild fish vs farmed fish (3.35), grass-fed livestock (3.16), animal welfare/animal rights (3.11), free-range poultry (3.05), and concentrated/confined animal feeding operations (CAFOs; 3.04).

\section{Attitudes About Teaching}

Respondents were asked to indicate their level of agreement on a variety of statements reflecting attitudes about interest in food systems and sustainability, confidence in teaching on these topics, and resource needs. Logical groupings of statements could not be substantiated by factor analysis or computation of internal consistency. The vast majority (82\%) of respondents agreed that educators of future nutrition and dietetic practitioners have a professional obligation to teach their students about sustainability issues; most (77\%) believed that their students do not appear to be interested in the sustainability of the food system; and more than half (62\%) agreed that the average American consumer lacks concern for this topic. Yet the majority $(68 \%)$ agreed that sustainability should be an important consideration for American consumers when making food choices. In keeping with these findings, three quarters of the respondents (77\%) were interested in learning how to incorporate information about food systems and sustainability into their pedagogy. About half of survey participants (52\%) agreed that they are confident in their own understanding of sustainability and the food system, but fewer (42\%) would be confident in teaching on topics related to the sustainability of the food system. Slightly more than half (57\%) already know where to look for information on these topics, but a strong majority of respondents (83\%) agreed that if the ADA provided teaching resources, they would consider using them. Finally, though a majority (63\%) agreed that there should be ADA foundation knowledge and skills competencies related to food systems and sustainability, nearly half (41\%) also agreed that incorporating new content into the dietetic curriculum would be a challenge. 


\section{Resource Needs}

According to survey participants, the types of resources that would be most useful include general curriculum guidance on food systems and sustainability; guidance for student assignments and research projects; class activities that promote discussion; and recommended reading lists. Participants would prefer Web-based training versus conference training or workshops or graduate coursework.

In the rest of this article we provide some conceptual, methodological, and literature-based resources for teaching sustainable food systems in college nutrition courses.

\section{Sustainable Food System Education Goals and Relevant Resources}

Taking into consideration the results of this survey and the need for resources, Table 1 is provided to help pinpoint conceptual underpinnings critical to creating a solid sustainability curriculum. This table lists and explains 7 evidence-based food system action goals that could significantly reduce global warming, improve global nutritional health, and maintain food resources for future generations. Key supporting resources, both evidence based and popular, are noted for each goal. These goals address topic areas for improving sustainable eating behaviors, as well as knowledge of sustainable agricultural practices, resource use, and social justice.

TABLE 1 Sustainable Food System Action Goals

1. Eat a healthful diet lower on the food chain $^{3,30}$ _Diversify the diet: reduce consumption of grain-fed meat, increase fruits, vegetables, and legumes. If desired, consume small amounts of humanely raised pastured or fodder-fed animal products.

2. Eat and act to promote sustainable farming/fishing practices $^{3,11,14,17,26,27,31,32}$ - Know how your food is produced; work to support sustainable growing practices and biodiverse agricultural/fishing systems.

3. Learn to cook, and appreciate cultural food patterns ${ }^{30-36}$-Cook and eat whole foods! Explore and celebrate traditional food patterns of diverse cultures; promote ethnic eating's environmental and health significance.

4. Reduce food transport energy $y^{10-13,36-39}$ —Eat foods in season. Create demand for locally produced/processed foods and support restaurants that buy this food.

5. Reduce food processing and packaging energy ${ }^{39,40}$-Eat fresh, lightly cooked, or efficiently stored local foods; cook using energy-saving techniques; avoid unnecessary containers and convenience packaging.

6. Reduce food waste and landfill methane production ${ }^{10,40-42}$-Keep consumption in balance with physiological requirements. Buy sparingly; eat leftovers, freeze for later, share or compost; keep food waste out of landfills.

7. Eat for social justice ${ }^{16,17,43,44}$-Share scarce resources. Support fair trade initiatives and local farming. Buy food that provides living wages and safe conditions for farm and food workers. 


\section{Integration in the Classroom}

Most nutrition courses offer opportunities to further students' understanding of sustainable food systems. In Table 2, we offer recommendations for integrating specific action goals into nutrition courses. The middle column of the chart outlines suggested pedagogical techniques.

Selected case examples give more detailed pedagogical methods for four of these goals based on the authors' experiences in their classes.

TABLE 2 Course-Indexed Didactic and Practical Lessons Teaching Sustainability

\begin{tabular}{|c|c|c|}
\hline Courses & $\begin{array}{l}\text { Pedagogical techniques for learning sustainability goals } \\
\qquad(\text { Table } 1)^{\mathrm{a}}\end{array}$ & Related action \\
\hline \multirow{6}{*}{$\begin{array}{l}\text { Food } \\
\text { preparation }\end{array}$} & Compost food scraps/recycling/recovering food & 6 \\
\hline & Demonstrate alternative products & $1,2,3,5,7$ \\
\hline & Explore local markets and farmers' markets & $3,4,5$ \\
\hline & Map seasonality, growth, harvest, transport & $2,4,6$ \\
\hline & $\begin{array}{l}\text { Students present controversial or comparative sustainable } \\
\text { food system topics }\end{array}$ & All \\
\hline & $\begin{array}{l}\text { Build understanding of food from soil to mouth; } \\
\text { human/economic dimension of food controversies }\end{array}$ & All \\
\hline \multirow{4}{*}{$\begin{array}{l}\text { Food service } \\
\text { management }\end{array}$} & Preparation using seasonal ingredients & $2,3,4,5$ \\
\hline & $\begin{array}{l}\text { Meal production project includes environmental impact } \\
\text { and conservation considerations }\end{array}$ & 1,2 \\
\hline & Practice food rescue & 6 \\
\hline & Growing food and composting at field site & 2,5 \\
\hline Life cycle & $\begin{array}{l}\text { Project: students trace historical changes in their families' } \\
\text { food system across } 3 \text { generations }\end{array}$ & $1,3,5,6$ \\
\hline \multirow[t]{4}{*}{$\begin{array}{l}\text { Community } \\
\text { nutrition }\end{array}$} & $\begin{array}{l}\text { Project: students design ideal community and examine } \\
\text { how land use and planning affect food availability }\end{array}$ & $1,2,4,7$ \\
\hline & $\begin{array}{l}\text { Students visit community and school gardens and } \\
\text { volunteer with school gardens or community-supported } \\
\text { agriculture }\end{array}$ & $2,3,4,7$ \\
\hline & $\begin{array}{l}\text { Students design a public scholarship project to improve } \\
\text { local food security and inform local officials }\end{array}$ & $1,2,4,5,6$ \\
\hline & $\begin{array}{l}\text { Build understanding of food system sustainability needs } \\
\text { and relationship to health }\end{array}$ & All \\
\hline \multirow{3}{*}{$\begin{array}{l}\text { Food and } \\
\text { society }\end{array}$} & Skill building in ethnic cooking and using local ingredients & $1,2,3,4,5$ \\
\hline & Build understanding of food system & All \\
\hline & $\begin{array}{l}\text { Contrast slow, cultural food to globalized, industrialized } \\
\text { food and the nutrition transition }\end{array}$ & All \\
\hline \multirow[t]{6}{*}{$\begin{array}{l}\text { International } \\
\text { nutrition }\end{array}$} & $\begin{array}{l}\text { Project: students present pros and cons of controversial } \\
\text { food system and farming issues }\end{array}$ & $1,2,4,5,6,7$ \\
\hline & Project: students calculate their ecological footprint & $1,2,4,5,6,7$ \\
\hline & $\begin{array}{l}\text { Project: students assess their own practices of sustainability } \\
\text { and design change in } 2 \text { areas }\end{array}$ & All \\
\hline & Integrate concept of slow food & $3,4,5$ \\
\hline & $\begin{array}{l}\text { Integrate concept of resource scarcity, climate change, and } \\
\text { nutrition impact }\end{array}$ & $1,2,5,7$ \\
\hline & $\begin{array}{l}\text { Integrate concept of locally appropriate diets and } \\
\text { contribution to health }\end{array}$ & $1,3,4,5,7$ \\
\hline
\end{tabular}

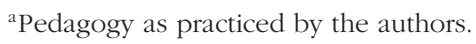


Goal 1: EAT a HeAlthful diet lower on the FoOd Chain; Goal 2: EAT AND ACT TO PROMOTE SUSTAINABLE FARM AND FISHING PRACTICES

In a Foods Preparation course, students work in pairs to research and present topics that complement each lecture. Topics covered during the semester facilitate critical analyses of conventional and sustainability-oriented methods of food production and preparation ${ }^{14,15,39}$ and include areas such as health claims, government food, nutrition and agriculture policies, and livestock production. Topics are framed as questions, and students are asked to research the sociological, health, and safety dimensions. Learning objectives of this project include (1) describing the complexity and often multidimensional quality of food systems; (2) explaining the impacts of consumer choice and government policy on farmers and food workers; (3) active engagement of students in researching, presenting, and writing about critical and emerging issues pertaining to the food system; and (4) deepening student appreciation for sustainability considerations related to food.

A Food and Society course explores current recommendations for healthful eating, in terms of disease prevention, ${ }^{2,5,24}$ within the context of human biophysical evolution, ${ }^{45,46}$ evolution of food systems, ${ }^{47-49}$ and current considerations of sustainability. ${ }^{1,3,6,8}$ Using the IUNS Giessen Declaration ${ }^{22}$ principles as a framework, students research and examine the contemporary nutritional health, food systems and environment, and global malnutrition and nutrition transition literatures to develop their own evidence-based "guidelines" for healthful eating based on these multiple considerations. Course learning objectives include (1) describing evidence for evolutionary influences on diet and health; (2) explaining sociopolitical events that have shaped contemporary food systems; (3) examining the pros, cons, and issues linked to the contemporary globalized food system; (4) developing research and critical analysis skills to consolidate information and draw conclusions substantiated by available evidence.

\section{GOAL 4: REDUCE FOOD TRANSPORT ENERGY}

Students in Community Nutrition work as a class on a service-learning project to create a local food guide to assist community members in selecting a nutritious diet of seasonally available foods found in the region. ${ }^{26,36-38}$ A team of student editors compiles the resource, which is distributed to audiences that include members of the university's garden and communitysupported agriculture program. Learning objectives for this project include (1) working effectively in small groups; (2) demonstrating writing and editing skills; (3) exploring aspects of the local food system including production, value-adding enterprises, farmers' markets, community-supported farms, and food retailers; and (4) developing recipes combining local foods available in each season. 
In Foods Laboratory courses, students sample and evaluate recipes that they prepare during classes. After each evaluation, students package food leftovers in reusable containers for later consumption. They return these containers empty, clean and ready for reuse by classmates. Pit, bin, and worm composting is addressed in lectures ${ }^{41}$ and then in practice through the composting of all raw fruit or vegetable peelings, cores, leaves, roots, or stems generated during lab activities. Learning objectives include (1) demonstrating engagement with urban agriculture, (2) exploration of the food and waste streams, (3) strategizing behaviors to reduce contributions to solid waste landfills.

\section{Additional Resources for Sustainability Education in Dietitian Training}

As noted, respondents to the survey believed that additional resources or guidance to integrate sustainability content into existing courses would be helpful. In addition to resources provided through this report, we also note two additional resources. The first is the ADA's continuing professional education module- "Healthy Land, Healthy Food, Healthy Eaters: Cultivating Sustainable Food Systems." 38 The second is an edited resource called "Teaching Food Systems and Sustainability in Nutrition and Dietetic Training: Lessons for Educators." 50 This is currently under development in collaboration with the American Dietetic Association Hunger and Environmental Dietetic Practice Group and is projected for release in 2011.

\section{SUMMARY}

In summary, concern about the health and sustainability of Earth's ecosystems has reached near critical mass. Many now argue that issues of global warming, hunger, and malnutrition can be partly addressed by changing the food systems that perpetuate these problems. Dietary patterns of consumers and the methods of food production and distribution antecedent to over- and underconsumption have well-documented implications for the well-being of humans and other threatened species. We urge educators in nutrition and dietetics training programs to consider the proffered methods for integrating these concerns into their courses, so that future nutritionists and dietitians can be leaders and advocates for food system practices that facilitate a healthy planet and healthy humans.

\section{REFERENCES}

1. Lang T. Food Policy: Integrating Health, Environment and Society. Oxford, UK: Oxford University Press; 2009.

2. Lang T, Heaseman M. Food Wars: The Global Battle for Mouths, Minds and Markets. London, UK: Earthscan Books; 2004. 
3. Jacobson MF. Six Arguments for a Greener Diet: How a More Plant-Based Diet Could Save Your Health and the Environment. Washington, DC: Center for Science in the Public Interest; 2006.

4. Brownell K. Food Fight: The Inside Story of the Food Industry, American's Obesity Crisis, and What We Can Do About It. New York, NY: McGraw-Hill; 2004.

5. United Nations Food and Agriculture Organization. Obesity: The Developing World's New Burden. Available at: http://www.fao.org/FOCUS/E/obesity/ obes1.htm. Accessed December 8, 2010.

6. Gardner G, Halweil B. Overfed and Underfed: The Global Epidemic of Malnutrition. Available at: http://www.Worldwatch.org. Accessed December 10, 2010.

7. United Nations Food and Agriculture Organization. Agriculture, Food and Water: A Contribution of the World Water Development Report. United Nations Educational, Scientific and Cultural Organization World Water Assessment Program; 2003. Available at: ftp://ftp.fao.org/agl/aglw/docs/ agricfoodwater.pdf. Accessed December 22, 2010.

8. Goodland R, Anhang J. Livestock and Climate Change: What If the Key Actors in Climate Change Are Cows, Pigs and Chickens? Available at: http://www. Worldwatch.org. Accessed December 10, 2010.

9. Monterey Bay Aquarium. Seafood watch. Available at: http://www.montereybayaquarium.org/cr/seafoodwatch.aspx. Accessed December 17, 2010.

10. Blair, D, Sobal J. Luxus consumption: wasting food resources through overeating. Agric Human Values. 2006;23:63-74.

11. Carlsson-Kanyama A, Gonzalez AD. Potential contributions of food consumption patterns to climate change. Am J Clin Nutr. 2009;89(suppl):1704S-1709S.

12. Energy Information Administration. Emissions of Greenhouse Gases Report: Methane Emissions. Available at: http://www.eia.doe.gov/oiaf/1605/ggrpt/ methane.html. Accessed November 10, 2010.

13. Scherr SJ, Sthapit S. State of the World: Into a Warming World. Available at: http://www.Worldwatch.org. Accessed December 10, 2010.

14. United Nations Food and Agriculture Organization. Livestock's Long Shadow: Environmental Issues and Options. Available at: http://www.fao.org/docrep/ 010/a0701e/a0701e00.htm. Accessed December 9, 2010.

15. Pew Commission on Industrial Farm Animal Production. Putting Meat on the Table: Industrial Farm Animal Production in America: Executive Summary. Pew Charitable Trusts and Johns Hopkins Bloomberg School of Public Health; 2007. Available at: http://www.livablefutureblog.com/pdf/ PuttingMeatonTableFullpdf. Accessed December 22, 2010.

16. Arcury TA, Quandt SA. The health and safety of farmworkers in the Eastern United States: a need to focus on social justice. In: Arcury TA, Quandt SA, eds. Latino Farm Workers in the Eastern United States: Health, Safety and Justice. New York, NY: Springer-Link Publisher; 2009:1-14.

17. Lyson TA. Civic Agriculture and the North American Food System. In: Hindrichs C, Lyson TA, eds. Remaking the North American Food System: Strategies for Sustainability. Lincoln, Neb: University of Nebraska Press; 2007:1-19.

18. Centers for Disease Control. US obesity trends. Available at: http://www.cdc. gov/obesity/data/trends.html. Accessed December 7, 2010. 
19. United States Department of Agriculture, Economic Research Service. Data sets. Available at: http://www.ers.usda.gov/data/FoodConsumption/. Accessed December 7, 2010.

20. Popkins BM. An overview of the nutrition transition and its health implications: the Bellagio meeting. Public Health Nutr. 2002;5:93-103.

21. Raschke V, Cheema B. Colonisation, the new world order, and the eradication of traditional food habits in East Africa: historical perspective on the nutrition transition. Public Health Nutr. 2007;11:662-674.

22. International Union of Nutrition Science. The Geissen Declaration. Available at: http://www.IUNS.org. Accessed December 7, 2010.

23. Raziano A. Creating a Safe Food System for America. Available at: http:// www.apha.org/NR/rdonlyres/D5D61048-7689-4642-8DFF-82933A2955AF/0/ FoodSafetyFinal.pdf. Accessed December 7, 2010.

24. American Medical Association. Medical schools, health care facilities can be healthy diet role models. Available at: http://www.ama-assn.org/ama/pub/ news/news/healthy-role-models.shtml. Accessed December 7, 2010.

25. Harmon, AH, Gerals BL. Position of the American Dietetics Association: food and nutrition professionals can implement practices to conserve natural resources and support ecological sustainability. J Am Diet Assoc. 2007;107:10331043.

26. Wilkins J. Eating right here: the role of dietary guidance in remaking community-based food systems. In: Hindrichs C, Lyson T, eds. Remaking the North American Food System. Lincoln, Neb: University of Nebraska Press; 2007:163-182.

27. Wilkins J, Lapp JL, Tagtow A, Roberts S. Beyond eating right: the emergence of civic dietetics to foster health and sustainability through food systems change. J Hunger Environ Nutr. 2010;5:2-12.

28. Harmon AH. Dietetic educator survey highlights: teaching on the food system and sustainability in the dietetic curriculum. ADA Hunger and Environmental Nutrition Newsletter. 2007; p. 4.

29. Teaching on the food system and sustainability in the dietetic curriculum: a survey of educators. J Am Diet Assoc. 2007;107(suppl 3):A-63.

30. American Institute of Cancer Research. The New American Plate: Meals for a Healthy Weight and a Healthy Life. Available at: http://www.aicr.org/site/ DocServer/E7B-NAPW.pdf?docID=1545. Accessed December 7, 2010.

31. Allen P. Together at the Table: Sustainability and Sustenance in the American Agrifood System. University Park, Pa: Penn State Press; 2004.

32. Slow Food International. Slow Food Web site. Available at: http://www. slowfood.com. Accessed December 9, 2010.

33. Rozin E. The Flavor Principles Cookbook. Portland, OR: Hawthorne Books; 1973.

34. GRACE. The sustainable table. Available at: http://www.sustainabletable.org/ kitchen/. Accessed December 12, 2010.

35. Nabhan P, Madison D. Renewing America's Food Traditions: Saving and Savoring the Continent's Most Endangered Foods. White River Junction, Vt: Chelsea Green Publishing; 2008. 
36. The Montana Food Guide: A Companion Resource for Seekers of Locally, Sustainably \& Educationally Grown Foods. Bozeman, Mont: Montana State University; 2008.

37. Appalachian Sustainable Agriculture Project. Local food guide for Western North Carolina and the Southern Appalachian Mountains. Available at: http://www.buyappalachian.org/. Accessed December 5, 2009.

38. American Dietetics Association. Healthy land, healthy food, healthy eaters: cultivating sustainable food systems. Available at: http://old.eatright.org/cps/ rde/xchg/ada/hs.xsl/education_22069_ENU_HTML.htm. Accessed December 7, 2010.

39. Canning P, Ainsley C, Huang S, Polenske KR, Waters A. Energy Use in the US Food System. Available at: http://www.ers.usda.gov/publications/err94/. Accessed December 12, 2010.

40. Cornell University College of Agriculture and Life Sciences and Division of Nutritional Sciences. Food packaging energy. Available at: http://www.swivel. com/data_sets/show/1007662. Accessed August 2, 2010.

41. Hanson B, ed. Easy Compost: The Secret To Great Soil and Spectacular Plants. 21st Century Gardening Series. Brooklyn, NY: Botanic Gardens Publications; 2005.

42. Themelis NJ, Ulloa PA. Methane generation in landfills. Renewable Energy. 2007;32:1243-1257.

43. Fair Trade Federation. Fair Trade Federation Web page. Available at: http:// www.fairtradefederation.org/. Accessed December 7, 2009.

44. W.K. Kellogg Foundation. Labor, social justice and the food system-food and society. Available at: http://www.wkkf.org/. Accessed December 7, 2010.

45. Leonard WR. Food for thought: dietary change was a driving force in human evolution. Sci Am. 2002; 287(6):106-115.

46. Milton K. Back to basics: why foods of wild primates have relevance for modern human health. Nutrition. 2000;16:480-483.

47. Diamond J. Guns, Germs and Steel: The Fates of Human Societies. New York, NY: W.W. Norton and Company; 1999.

48. Pelto P, Pelto GH. Diet and delocalization: dietary changes since 1750. J. Interdiscip Hist. 1983;14:507-528.

49. Levenstein H. Paradox of Plenty: A Social History of Eating in Modern America. Berkley, Calif: University of California Press; 2003.

50. Harmon AH, Forbes C, Odermann J, Wharton C, Sarjahani A, French G, Roach R, Rouder C, Webber CB, Tagtow A, eds. Teaching Food Systems and Sustainability in Nutrition and Dietetic Training: Lessons for Educators. American Dietetic Association Hunger and Environmental Dietetic Practice Group, as a service to dietetic educators. (In preparation). 